\title{
An Analysis of Initiation Response Feedback (IRF) Pattern in Classroom Discourse at Half Nelson Movie
}

\author{
Rifika Chandra ${ }^{1}$, Yulmiati ${ }^{2}$, Edwar Kemal ${ }^{3}$ \\ 'STKIP PGRI Sumatera Barat, Padang, rifikachandra@gmail.com \\ ${ }^{2}$ STKIP PGRI Sumatera Barat, Padang,yulmiati@gmail.com \\ ${ }^{3}$ STKIP PGRI Sumatera Barat, Padang, edwarkemal@gmail.com
}

(C)2021 by the authors. Submitted for possible open access publication under the terms and conditions of the Creative Commons
Attribution-ShareAlike 4.0 International License-(CC-BY-SA) (https://creativecommons.org/licenses/by-sa/4.0/)
d) DOI: bttps://10.30983/mj.v111.4835
\begin{tabular}{|l|c|c|}
\hline Submission: September 17, 2021 & Revised: December 05, 2021 & Published: December 31, 2021 \\
\hline
\end{tabular}

\begin{abstract}
Abstrak
Latar belakang penelitian berdasarkan observasi peneliti dalam film Half Nelson yang menunjukekan babwa terdapat pola IRF yang digunakan selama interaksi antara guru dan siswa di dalam kelas. Tujuan dari penelitian ini adalah untuk. mengetahui bagaimana pola IRF terjadi di dalam kelas, bagaimana guru berinisiatif, bagaimana respon siswa, dan bagaimana umpan baliknya. Penelitian ini dilakukan dengan menggunakan penelitian kualitatif dengan menggunakan pendekatan analisis wacana dalam linguistik. terapan dan menggunakan metode deskriptif. Data dalam penelitian ini adalab interaksi yang terjadi ketika guru dan siswa saling berinteraksi dalam naskah film Half Nelson. Penelitian ini menggunakan purposive sampling sebagai teknik, pengumpulan data. Hasil penelitian ini menunjuk.kan bahwa ada enam jenis inisiasi yang digunakan, yaitu teacher elicit, teacher direct, teacher inform, teacher listing, reinisiation (i), re-initiation (ii). Respon tersebut adalab respon siswa spesifik, silent, silent-av, bingung berorientasi kerja, tertawa, respon siswa open-ended, dan nonverbal. Jenis-jenis umpan balik adalab mengulang, mengakui jawaban yang benar, memperluas atau memodifikasi, menunjukkan jawaban yang salah, meringkas, memuji. Berdasarkan hasil analisis data, dapat disimpulkan bahwa guru menggunakan berbagai jenis inisiasi dalam situasi yang berbeda.
\end{abstract}

Kata Kunci: Pola IRF, Film Half Nelson, Interaksi

\begin{abstract}
The background of the research based on the researcher observation in Half Nelson movie which indicated that there was an IRF pattern used during interactions between teachers and students in the classroom. The purpose of this study is to find out how the IRF pattern occurs in the classroom, how the teacher initiates, how students respond, and how the feedback. This research was conducted using qualitative research by using a discourse analysis approach in applied linguistics and using descriptive methods. The data in this study is the interaction that occurs when teachers and students interact with each other in the Half Nelson movie script. This study uses purposive sampling as a technique in data collection. The results of this study indicate that there are six types of initiation used, namely teacher elicit, teacher direct, teacher inform, teacher listing, re-initiation (i), re-initiation (ii). The responses are students' response specific, silent, silent-av, confused work-oriented, laughter, students' response open-ended, and nonverbal. The types of feedback are repeating, acknowledging a correct answer, expanding or modifying, indicating an incorrect answer, summarizing, praising. Based on the results of data analysis, it can be concluded that the teacher used various types of initiation in different situation.
\end{abstract}

Keywords: IRF Pattern, Half Nelson Movie, Interaction

\section{Introduction}

Discourse is the study of words used in communication or engagement. The use of written and spoken language in a social situation is referred to as discourse. In this context, the term discourse refers to a wide range of purposes, all of which are related to language. Furthermore, discourse refers to the study of language used in interaction to explore what the interlocutors think, believe, feel, wish, and so on (Suherdi, 2010). Based on the definition of discourse, discourse can be defined as the analysis of language used both written and spoken in context of social life through interaction. 
Interaction is an important part for our life. In interaction, we can get information or share idea, mind, opinion to get respond from others. Interaction is a reciprocal action that takes an action and gets a respond from others (Dagarin, 2004). Therefore, interaction in classroom is main point to get the knowledge that teacher share for students while teaching and learning process in classroom.

Context is the most important clue to the meaning of discourse (Azizifard and Jalali, 2012).. Context refers to the situation whether the language takes place, for example what topic, to whom, where, and when it influences the meaning. Therefore, context is very important in analyzing the meaning of the discourse. People will know the meaning of discourse after understanding the context.

In this research, the researchers studied about classroom discourse as one of context in social situation. Classroom discourse differs in form and function from language used in other situation because of the particular social roles that students and teachers have in the classroom (Behnam \& Pouriran, 2009b). It can be defined as an analysis of language used in situations where the participants are students and teachers interacting in the classroom. Interaction in classroom occurs when the students actively give respond such as giving idea/ideas, ask/answer question from the teacher. Interaction that occurs between teachers and students are usually two-way communication.

Initiation-Response-Feedback (IRF) pattern can be used to see the interaction between teacher and student in classroom when they do interaction each other. IRF pattern is situation where the teacher gives a question for students and students give the respond, and then the teacher gives the feedback for the respond. The example of IRF pattern can be seen in the discourse below:

Teacher: what's the capital of Trance?

Students: Paris.

T: Yes Paris. That's right.

(Example by : Rezaie \& Lashkarian (2015)

The analysis of teaching and learning language and interaction is typically related with the study of classroom discourse (Markee, 2015). Classroom discourse refers to the language used by teachers and students in classroom interaction, during classroom teaching processes teaching learning process. Classroom discourse is a small part of discourse within the meaning of language in use. So, classroom discourse is the language used by all participants when they interact with each other in classroom. Understanding classroom discourse is a key of success in understanding education in action. Interaction analysis method found a suitable strategy to achieve the best result for it, it is called IRF (Initiation, response, and feedback). It becomes a pattern that used in interaction, involving as the study in educational research on teaching practices (Christie, 2002).

Some researchers have studied about IRF. Ramli (2020) found that the gender performance gap cannot be attributed to stereotypical gender role models. The study shows that the domination of one gender in each of these classes is not caused by a gender stereotype, but rather is due to the teacher's strategies in maintaining social interaction in their classes (Ramli, 2020). It also found that there are various types of classroom interaction patterns occur in the classroom. From those various patterns, simple non anomalous K1 initiated patterns dominate the interaction between teacher and students in the classroom (Amin, 2015). These previous studies analyzed teacher and students interaction during teaching and learning process in 
classroom. Meanwhile there is limited research analyze about Initiation, Response, And Feedback (IRF) as the focus of this research.

Initiation or opening moves, according to Sinclair \& Choulthard (Ginting, 2017), is the beginning of a teacher-led dialogue. The opening move is realized by ten exchanges. They are: 1) Teacher Elicit: teacher's initiation to encourage students to speak up, 2) Teacher Inform: teacher's first action to tell students with facts, opinions, ideas, or fresh knowledge, 3). Teacher Direct: getting students to do something but not say anything, 4) Teacher Listing: initiation that doing by teacher to get two or more responses from students in order to ensure that how many students understand, 5) Re-initiation (i): When an elicitation fails to elicit a response, the teacher can try again with the same or a similar question, or he can employ one or more of the following strategies, 6) Re-initiation (ii): When a teacher receives an incorrect response to an elicitation, she initiates a bound initiation. She has two options: she can continue with the same student and use the Socratic technique to work her way to the correct answer, or she can stay with the same question and re-initiate with another student, 7) Teachers want to find out how well their students are doing. Reinforce: When the teacher tells the class to perform something and one student is delayed, hesitant, or doesn't understand, bound exchanges ensue, 8) Repeat: when teacher explain the material but some students not hear or pay attention to the teacher, she can repeat what her said, 9) Bound Initiation: When a teacher receives no or an incorrect answer, the teacher may repeat or rephrase the question, or she could have moved on to another student in this situation.

Interaction analysis, often known as Foreign Language Interaction (FLINT) is supported theory by Sinclair of IRF pattern. Brown (2000) state that there are variety of students responses. They are: 1) Students response specific: Drills, reading aloud, dictation, and responding to the teacher within a specific and limited range of accessible or previously performed replies, 2) Silence: pauses in the interaction. 3) Laughter: students are simply smiling and giggling in class when the teacher tells jokes to lighten the mood of the students in a lesson that is a little serious, 4) Confusion: there are many students talking at the same moment, making it impossible to record the conversation, and 5) Nonverbal: students communicate without using words but using gestures or facial expressions.

Positive or negative feedback is possible (Richards \& Lockhart, 1994). Feedback content is a collection of different types of feedback available on material. They are: 1) Acknowledging a correct answer: the teacher acknowledges the correctness of a student's response by saying: "Good", "that's right", or "exactly", 2) Indicating an incorrect answer: when a teacher says, "This student's answer is incorrect," the teacher implying that the student's answer is inaccurate, 3) Praising: The teacher compliments a student for an answer, 4) Expanding or modifying: When a student's answer is ambiguous or incomplete, the teacher responds by offering further information or rephrasing the answer in the teacher's own words, 5) Repeating: The teacher repeats the student's answer, 6) Summarizing: The teacher summarizes what a student or a group of students said, 7) Criticizing: The teacher criticizes the students' answers.

In this research, the researchers used a movie entitled Half Nelson to find some phenomena that related with this research. Half Nelson provides an interesting treat about the teacher and his relationship with students. The purpose of this research is to analyze the pattern of interaction and to investigate how are the IRF patterns of classroom discourse that is used in Half Nelson movie. The researcher wants to investigate how the teacher initiates the interaction in the classroom, how the students response and how the teacher feedback the interaction in teaching 
learning process. the researchers had three research questions in conducting this research. Research question of this research could be elaborate as: how are the teacher initiation patterns in classroom at Half Nelson movie, how are the students' response patterns in classroom at Half Nelson movie, how are the teacher feedback patterns in classroom at Half Nelson movie

\section{Method}

Related to the purpose of this research, the researcher used qualitative approach with the descriptive research design. The researcher used focused on IRF pattern in classroom discourse that used by teacher during teaching and learning process in a movie entitled Half Nelson. The aim of descriptive research is to describe a phenomenon and its characteristics (Nassaji, 2015). It means that to describe or explain in detail the phenomena that occur in the field and describe the characteristic forms of these phenomena. In this research, Researcher used the script of Half Nelson movie as a source of data about IRF pattern in classroom discourse. The researcher focused on IRF pattern in classroom discourse used by teacher and students in this movie.

Purposive sampling was used in selecting sample in this research. The researcher identified the characteristics of sample as the aim of the research (Paltridge \& Phakiti, 2018). In getting source of data, the researcher selected a sample that suitable with the characteristic of this research. The researcher focused on teacher's discourse in teaching and learning process in getting the data about IRF pattern as found in Half Nelson movie.

\section{Finding and Discussion}

\section{IRF Patterns}

Firstly is initiation (I), the movement in which teacher initiates an interaction, initiation is the teacher ask a question or action to initiate students to do interaction in classroom. Secondly response moves $(\mathrm{R})$, what is actually performed by the students following the initiation which produced by the teacher. Response is representing the teacher initiate in response of initiation move by participants act. The last is feedback/follow up (F), the last exchange of a turn which aims to give feedback to students' response. feedback completes the cycle as it provides closure to the initiation and response, Rustandi \& Mubarok (2017).

\section{Initiation Patterns}

The following data are the initiation pattern found in Half Nelson movie.

\section{a. Teacher Elicit}

In the morning, when the bell is ringing, the students enter the class and waiting for the teacher come. The students talking each other until the teacher enter the class and students start to silent and pay attention to the teacher. The teacher writes in the whiteboard about the meaning of history. The topic that discussed was about history, after that teacher throws glasses that make students pay attention to the teacher. The teacher initiates the conversation by giving a question to the students. Thus this following dialogue at 00.02 .29 minute occurred.

\section{Teacher : What is history? \\ Student 1 : Opposites \\ Teacher : You can read the board. \\ Students : (laughter) \\ Teacher :I am so happy to hear that.}

The words "What is history?" are the initiation from the teacher to initiate the interaction to students. To guide students' response, the teacher raises a question to the students about the meaning of history. The teacher begins the interaction by asking a question to the students to obtain verbal contribution from students. This is called teacher elicit because the interaction first 
begins from the teacher that raises a question for students. Next, one of students response by saying “Opposites" those words are the response given by student to the teacher initiation. The students answer is wrong, because the student 1 answer the question based on what him read on the whiteboard. It is response including to type of student response specific. It means students answer the question based on what they got from what they read in the whiteboard. Last, the feedback of teacher is laugh and said "you can read the board" its explain that the answer from students is incorrect but the teacher still happy because there is student response what the teacher said. Its feedback namely indicating an incorrect answer. So, the IRF pattern in this dialogue is the initiation is teacher elicit, the response types is students response specific and then the feedback types is indicating incorrect answer and praising.

\section{b. Re-initiation (ii)}

The students keep silent and pay attention to the teacher. The teacher trying initiates the conversation by giving a question to the students. One student raises his hand and answer the question. The student's answer was not accurate, so the teacher asks again with the same question, thus this following dialogue at 00.02 .38 minutes occurred.
Teacher : No, what is it? What does it mean?
Student : (raise her hand)
Teacher : Stacey?
Student : Change?
Teacher : Thank you Stacey, I am glad to hear someone is paying attention. History is the study of change over time.

From the dialogue above the teacher repeated the question to initiate the interaction between students. To guide students' response, the teacher raises a question to the students about the meaning of history. The teacher begins the interaction by asking a question to the students to obtain verbal contribution from students. The students answer for elicitation was incorrect, so the teacher asked again by said "no, what is it? What does it mean?". The types of initiation called re-initiation (ii). In the first dialogue the teacher asked about the meaning of history and one student answered it. However, in next dialogue the teacher asked again the same question. It means that the students answer before is incorrect, so the teacher use re-initiation to initiated the interaction.

\section{c. Listing}

After giving explanation or summary about the meaning of history, the students look bored then the teacher give an example and try to ask the students more examples. Thus this following dialogue at 00.03.19 minutes occurred.

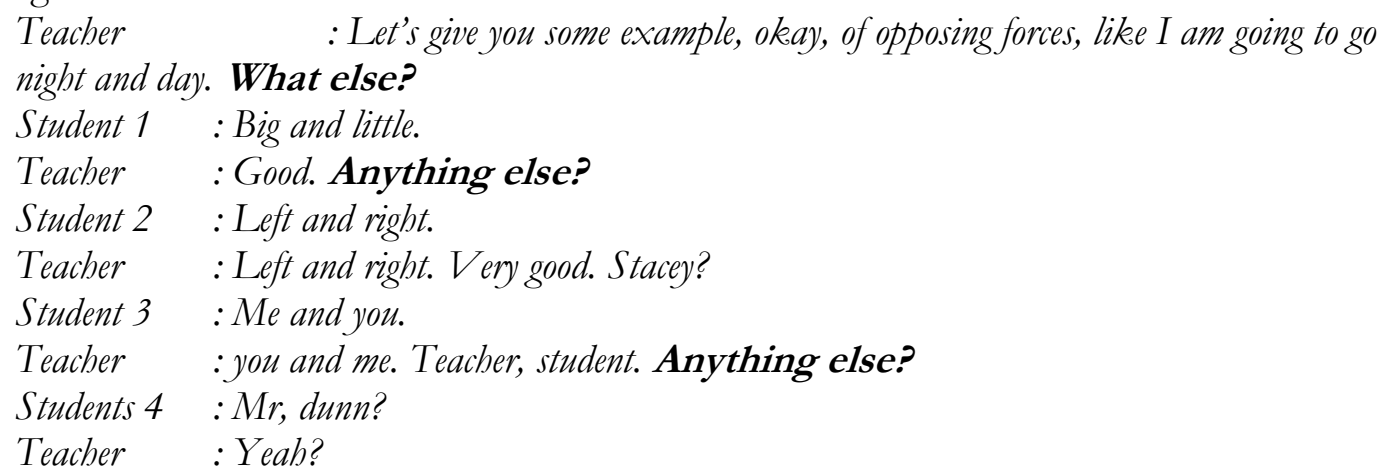

From the dialogue above, the initiation that doing by teacher is listing. It is situation where the teacher hearing the answer from three or more students to make sure how many students understand. It can be seeing when the teacher saying "what else? Anything else?" It means the teacher wants to know how many students understand about the material. 


\section{d. Teacher inform}

In the morning at class, the teacher and students are already in classroom. They are busy for they business each other while waiting for the bell to signal the start of the lesson ring. When the bell is ringing, and all of students have gathered in class the teacher start to interact with students. Thus this following dialogue at 00.02.46 minutes occurred.

Teacher : well, I feel good today. Anyone else feel good? Hmm?

Students : (silent)

Teacher : I need a volunteer, and I need somebody who feels strong.

Student 1 : (one of students being a volunteer)

Teacher :So what we've got here is two opposing forces, Terrence and myself, and we're pushing against each other. And as long as one is stronger-- and it looks like it's t-the change is slow and consistent. but once the other side becomes stronger, there's a turning point.

Students :(paying attention and laughter)

Teacher :Thank you Tee. Make sense? Okay. Now, turning points can happen like that. They can be physical, or they can happen on a greater scale, like a war or something.

Based on the dialogue above the teacher doing initiation by giving explanation about what they do in front of the class. This initiation is called teacher inform, because the teacher doing an action but while explaining what he was doing and talk about the material related to the action. It is situation where the teacher giving information or explanation about the material that they discuss at that time.

\section{e. Teacher Direct}

To start the lesson, the teacher asks one of students who feel strong for strength fight and that activity the teacher explain the purpose of that. Thus this following dialogue at 00.23.57 minutes occurred.

Teacher :So what we've got here is two opposing forces, Terrence and myself, and we're pushing against each other. And as long as one is stronger-- and it looks like it's t-- the change is slow and consistent. but once the other side becomes stronger, there's a turning point.

Students :(paying attention and laughter)

Teacher :Thank you Tee. Make sense? Okay. Now, turning points can happen like that. They can be physical, or they can happen on a greater scale, like a war or something. So why don't you do me a favor and write three examples of historical turning points that we've talked about in class, okay?

Students : (students take a book).

From the dialogue above, after give explanation and practice to students, the teacher gives students assignment. It activity is an initiation called teacher direct. It can see in the dialogue when the teacher said, "Why don't you do me a favor and write three examples of historical turning points that we've talked about in class, okay?" thus words are instruction from the teacher to ask students doing the activity. It is situation where after the teacher explains about the material, teacher gives assignment to the students.

\section{f. Re-initiation (i)}

In the morning at class, the teacher playing a video about history and after that they discuss what a video talking about. Thus this following dialogue at 00.36 .21 minutes occurred.
Teacher : (playing a video)
Students : (watching a video)
Teacher : what is the machine that he is talking about?
Students : (silent)
Teacher : its keeping us down. What is it?
Student 1 : like robots and stuff, right? 
Teacher : it could be robot. It could be robot, but let's say it's a metaphor. he's saying this machine is keeping me down. Now, what is that? What keep us being free?

Student 2 : (raise her hand) prisons.

Teacher : absolutely, absolutely. Prisons, okay? Prisons are definitely a part of it. What else?

Students 3 : white.

Teacher : white is definitely a part of it. The man.

Student 4 : the school

Teacher : the school, exactly. The whole education system is part of the machine. What else?

Student 5 : aren't you the machine then?

From the dialogue above, the teacher initiate the conversation by asks students about what a video talking about, but no response from students and then the teacher give a clue to students and asks again. The initiation doing by teacher called re-initiation (i). It can be seeing in the dialogue when teacher said "its keeping us down. What is it?" teacher give a clue for students and asks the question again. It is the situation when teacher get no response for elicitation, the teacher start again the conversation giving a question.

\section{Response patterns}

The second classification of interaction pattern in classroom discourse was response. Response moves that what is actually performed by the students following the initiation which produced by the teacher. It is a reaction in the form of an action either verbal or nonverbal.

a. Students response specific

In the morning, when the bell is ringing, the students enter the class and waiting for the teacher come. The students talking each other until the teacher enter the class and students start to silent and pay attention to the teacher. The teacher writes in the whiteboard about the meaning of history. The topic that discussed was about history, after that teacher throws glasses that make students pay attention to the teacher. The teacher initiates the conversation by giving a question to the students. Thus this following dialogue at 00.02 .29 minute occurred.

Teacher : What is history?

Student 1 : Opposites

Teacher : You can read the board.

From the dialogue above, the teacher initiate the conversation by giving a question to the students, one of students response by saying “opposites" its answer is wrong question because the student 1 answer the question based on what him read on the whiteboard. It is response including to category of student response specific. It means students answer the question based on what they got from what they read in the whiteboard.

\section{b. Students response open ended}

The teacher talking about explanation the meaning of history and then saw some students look bored. The teacher tried to guide students speak up during learning by asks more than one students. Thus this following dialogue at 00.03.19 occurred. else?

Teacher : Let's give you some example, okay, of opposing forces, I am going to go night and day. What

Student 1 :Big and little.

Teacher : Good. Anything else?

Student 2 : Left and right.

Teacher : Left and right. Very good. Stace?

Student 3 : Me and you.

Teacher :you and me. Teacher, student. Anything else?

Students $4: M r$, dunn?

Teacher :Yeab? 


\section{Students 4 : Just wondering if you could count me and Gina's baldheaded sister as opposites. \\ Students : (students making noise)}

From the dialogue above, the teacher initiate the lesson by asks more than one students answer the question. There are some students' answers the question from teacher. The response that given by students such as "Big and little, left and right., Me and you, Just wondering if you could count me and Gina's baldheaded sister as opposites". From thus words, the students answer the question based on the students' knowledge. It is depend on their idea or what they thinks.

\section{c. Confusion work oriented}

The teacher talking about explanation the meaning of history and then saw some students look bored. The teacher tried to guide students speak up during learning by asks more than one students. Thus this following dialogue at 00.03 .38 occurred.

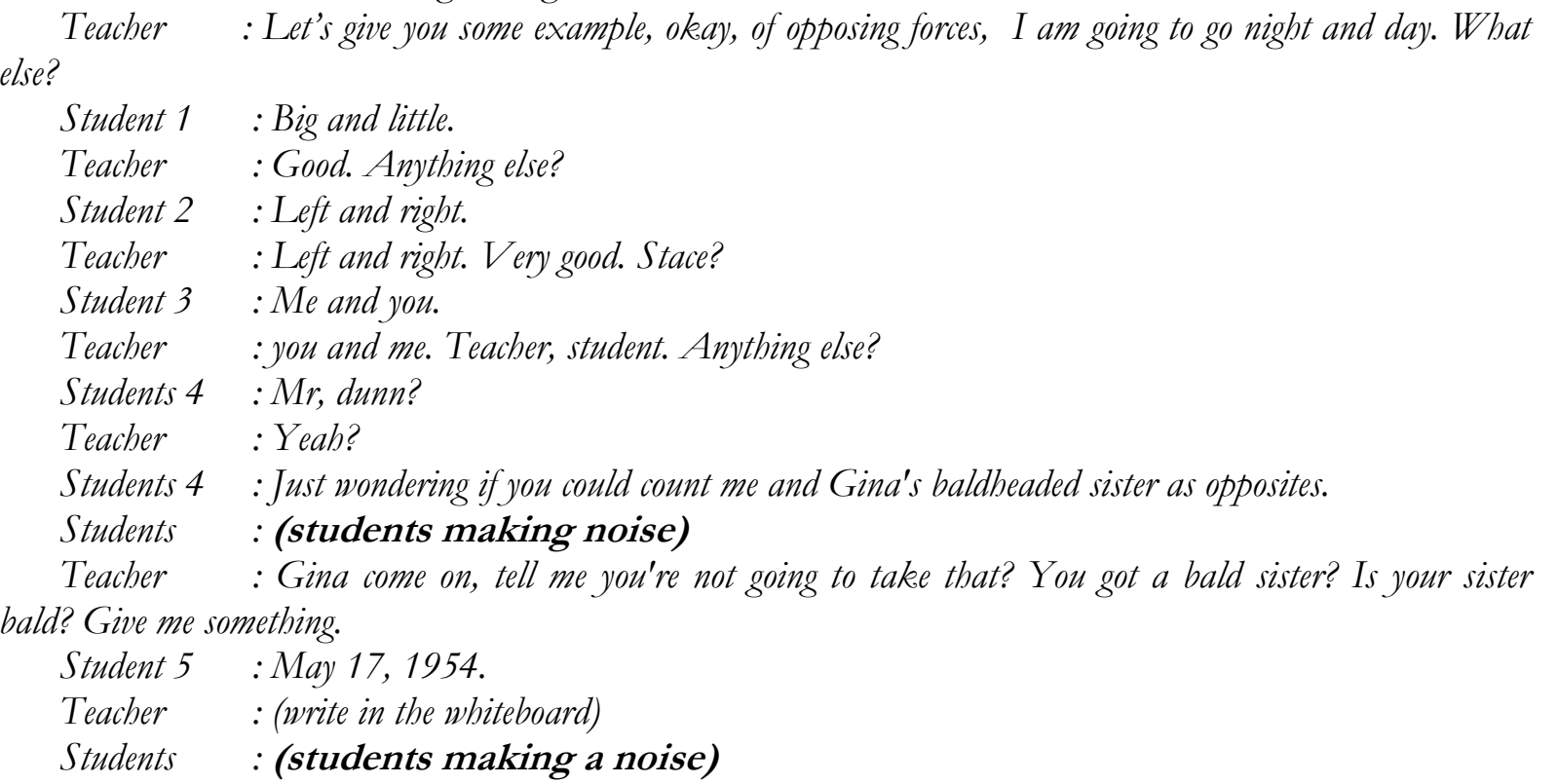

From the dialogue above, one of students answer the question based on what they he thinks, it makes other students making a noise. This response including to category of confusion work oriented. It is the situation where more than one students talking during the interaction.

\section{d. Silent-AV}

In the morning, the teacher and students are already in classroom. They are busy for they business each other while waiting for the bell to signal the start of the lesson ring. When the bell is ringing, and all of students have gathered in class the teacher start to interact with students. Thus this following dialogue at 00.02.46 minutes occurred. Thus this following dialogue at 00.23.55 occurred.

Teacher : Well, I feel good today. Anyone else feel good? Hmm? I need a volunteer, and I need somebody who feel strong.

Student : (one of students comes being a volunteer)

Teacher :So what we've got here is two opposing forces, Terrence and myself, and we're pushing against each other. And as long as one is stronger-- and it looks like it's t-- the change is slow and consistent. but once the other side becomes stronger, there's a turning point.

\section{Students :(paying attention to the action what the teacher do)}

From the dialogue above, the teacher doing an action but while explaining what he was doing and talk about the material related to the action. The response by students in the dialogue is silent-AV. It is the situation where the students just keep silent and pay attention. 


\section{e. Gesture}

To start the lesson, the teacher asks one of students who feel strong for strength fight and that activity the teacher explain the purpose of that. Thus this following dialogue at 00.24.24 minutes occurred.

Teacher :Okay. Now, turning points can bappen like that. They can be physical, or they can bappen on a greater scale, like a war or something.

Students : (pay attention)

Teacher :So why don't you do me a favor and write three examples of historical turning points that we've talked about in class, okeay?

\section{Students : (students take a book).}

From the dialogue above, after the teacher explain about the material, the teacher do the teacher direct initiation that is giving a task from students. The students response what the teacher asks by gesture not answer but doing the activity. These responses enter the category students' response nonverbal.

\section{f. Silent}

In the morning at class, the teacher playing a video about history and after that they discuss what a video talking about. Thus this following dialogue at 00.36 .21 minutes occurred.

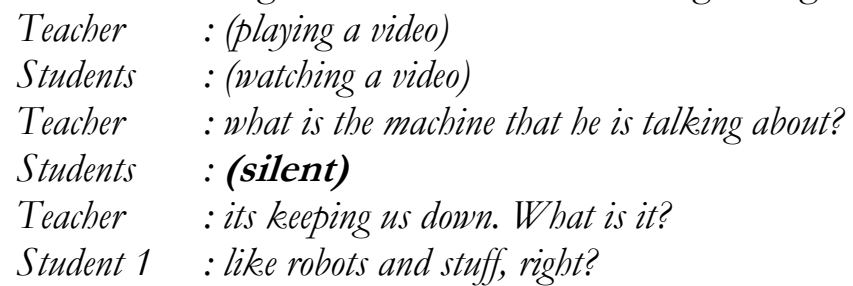

From the dialogue above, the teacher play a video and the students watching it. After that the teacher turn off the video and do the elicitation initiation by giving a question but the students just silent or no response because they are do not know the answer and at the time happened pause the interaction. Then teacher do re-initiation to the students.

\section{Feedback patterns}

The last classification of interaction pattern in classroom discourse was feedback. Feedback is the situation where the teacher gives a question to the students and the students give response then at the time teacher evaluate the students answer. Not all response needs feedback from the teacher because feedback is appreciation by teacher to student who talks in the class.

a. Indicating an incorrect answer

Thus this following dialogue at 00.02.29 occurred.

Teacher : What is history?

Student 1 : Opposites

Teacher : You can read the board.

Students : (laughter)

Teacher : I am so happy to hear that

Teacher : No. What is it? What does it mean?

From the dialogue above, the teacher asks to students about the meaning of story and one student answer it opposites, the feedback of teacher is laugh and said "you can read the board" its explain that the answer from students is incorrect but the teacher still happy because there is student response what he say. Its feedback enters the category indicating an incorrect answer.

\section{b. Praising}

Thus this following dialogue at 00.02 .38 occurred.

Teacher : No, what is it? What does it mean? 


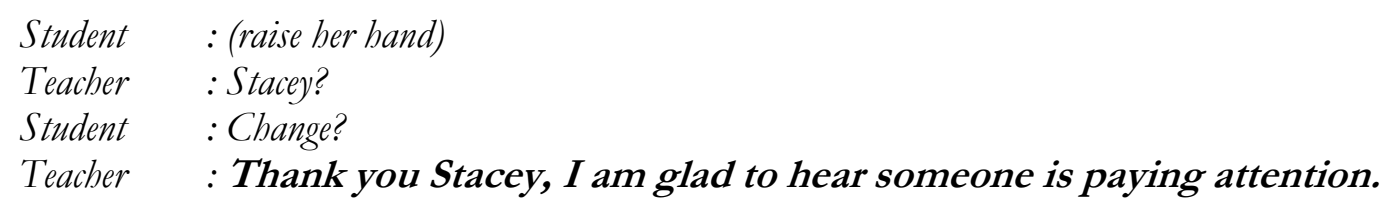

From the dialogue above, after give feedback to students who answer the question but the answer was incorrect, the teacher do re-initiation by asks again to other students, and one students answer it. The teacher gives feedback by saying "Thank you Stacey, I am glad to hear someone is paying attention" that word explain that the teacher give appreciate or compliment to the student who answer it.

\section{c. Repeating}

Thus this following dialogue at 00.03.19 occurred.

Teacher : Let's give you some example, okeay, of opposing forces, like I am going to go night and day. What else?

Student 1 : Big and little.

Teacher : Good. Anything else?

Student 2 : Left and right.

Teacher : Left and right. Very good. Stacey?

Student 3 : Me and you.

Teacher : you and me. Teacher, student.

From the dialogue above, the teacher initiate the lesson by asks more than one students answer the question. And then the teacher give feedback by repeat the students answer by said "Left and right". Its feedback enters the category of repeating. Because the teacher repeat what the students said.

\section{d. Summarizing}

Thus this following dialogue at 00.23 .55 occurred.
Teacher :So what we've got here is two opposing forces, Terrence and myself, and we're pushing against each other. And as long as one is stronger-- and it looks like it's t-- the change is slow and consistent. but once the other side becomes stronger, there's a turning point.
Students :(paying attention to the action what the teacher do)
Teacher :Okay. Now, turning points can happen like that. They can be physical, or they can happen on a greater scale, like a war or something.

From the dialogue above, after explain the material that they discuss at the time the teacher conclude that. This feedback enters the category of summarizing.

\section{e. Expanding or modifying}

Thus this following dialogue at 00.36 .21 occurred.

Teacher : what is the machine that he is talking about?

Students : (silent)

Teacher : its keeping us down. What is it?

Student 1 : like robots and stuff, right?

Teacher : it could be robot. It could be robot, but let's say it's a metaphor. He is saying this machine is keeping me down.

From the dialogue above, the teacher asks the students about the video but no one students answer it because they do not know the answer, the teacher provide instructions to make it easier for students answer it, one students trying to answer that question. The category of feedback gives by teacher is expanding or modifying because the teacher said, "It could be robot, but 
let's say it's a metaphor". Those words explain the answer from students is incomplete and the teacher provides more information.

f. Acknowledging a correct answer

Thus this following dialogue at 00.36 .21 minutes occurred.

Teacher : Now, what is that? What keep us being free?

Student 2 : (raise her hand) prisons.

Teacher : absolutely, absolutely. Prisons, okay? Prisons are definitely a part of it. What else?

Students 3 : white.

Teacher : white is definitely a part of it. The man.

Student 4 : the school

From the dialogue above, the teacher asks the students about the video, the teacher provide instructions to make it easier for students answer it, one students trying to answer that question. The category of feedback gives by teacher is acknowledging a correct answer because the students answer is correct. The words, "absolutely, absolutely. Prisons, okay? Prisons are definitely a part of it". Those words explain the answer from student was correct.

In this section, the researcher summarized the research findings. First, the findings were related to types of initiation in classroom discourse used by the teacher in balf Nelson movie. The researcher classified those types based on Brown (2000). The researcher then found six types of initiation in classroom discourse used by the teacher in Half Nelson movie. Then, the researcher found six types of response that given by students in Half Nelson movie. The last researcher founds six types of feedback that used by teacher to evaluate students answer.

Referring to the data analysis, the researcher found 10 dialogues as the data in this research. From the table above, first the teacher use three times teacher elicit to initiate the interaction in classroom during teaching and learning process. There are several type of responses given by students to teacher elicit or elicitation are students response specific, students response open ended by their own ideas, pause the interaction as silent because the student was not know the answer and sometimes students response by laughing. Second, in teaching and learning process the teacher used twice of teacher informs to initiate the interaction. The response given by students to teacher informs is silent because the students pay attention what the teacher explain.

Third, the teacher used one time of teacher direct to initiate the interaction. The response given by students is nonverbal because the response by use word is not necessary in this initiation, the students only need doing what the teacher ask. Forth, the teacher used twice of listing to initiate the interaction during teaching and learning process. The response given by students for listing are students response open-ended and confusion work oriented because the students excited to the lesson and there are more than one students talked during the lesson. Fifth, the teacher used one time of re-initiation (i) to initiate the interaction in classroom. The students' gave open- ended response for re-initiation (i).

Last, the teacher used one time of re-initiation (ii) to initiate the interaction in classroom. The students gave open-ended response for re-initiation (ii). The response given by students was open There were four kinds of initiation that did not use by teacher such as reinforce, check, repeat, and bound initiation. The first is reinforce it is the situation where the teacher restate to students to do the activity what the teacher command before, this initiation commonly use when there some students don not allow the lesson and do not want to do the activity but in this movie does not show a scene where students are working on assignment. Second is check, it is situation where the teacher checking whether the students understand or not, in this movie the teacher do not use this types because during teaching and learning process the students follow the lesson and pay attention to the teacher, the students give a good response while teaching and learning process. Next repeat is the situation where the teacher repeats the explanation when the students do not hear or pay attention but in this movie the students happy to study with the teacher and 
always follow the lesson so there is no need to use these types of initiation. Last bound initiation is the situation where the teacher moves to ask another student when the first student cannot answer the question. After watched the Half nelson movie the teacher did not use reinforce, check, repeat, and bound initiation because the students pay attention to the teacher during teaching and learning process. Students were understood and follow the lesson and there is no negative response.

Next, the researcher classified teacher feedback in interaction between teacher and students in Half Nelson movie. Based on theory there are seven types of feedback that can use by teacher to evaluate students response. However, in the finding the researcher found six types of feedback that used by teacher in Half Nelson movie. The findings are repeating, acknowledging a correct answer, expanding or modifying, indicating an incorrect answer, summarizing and praising. Only one type of feedback did not use by the. teacher that is criticizing. It is the situation where the teacher criticize the students answer. Criticizing is not good to use because it is make students sad and make students not comfortable. A good teacher would give appreciate on the courage of students in participating in class. Criticizing is negative feedback, the teacher got positive response from students so criticizing is not necessary to use.

\section{Conclusion}

Based on the explanation above, the findings of this research show that, the interaction between the teacher and students in Half Nelson movie is using IRF pattern. In this movie, the teacher not only uses one type of initiation, the teacher used a variety of initiation in different situation. IRF is two ways communication process between teacher and students in learning activity. The researchers concluded that the interaction between teacher and students was suitable with IRF pattern. The interaction pattern between teacher and students was complete. There was initiation, response and feedback during teaching and learning process in Half Nelson movie. Interaction in classroom is two-way communication and warm. The students respect to the teacher and students in the classroom was responsive. So, the communication between teacher and students in Half Nelson movie was good.

\section{References}

Amin, A. R. (2015). Patterns of Teacher Students Interaction A Case Study of Classroom Interaction in Eleventh Grade of Senior High School in Cimahi. Journal of English and Education 2015, 3(1), 14-29, 3(1), 14-29.

Azizifard, F., \& Jalali, S. (2012). Context and humor in teaching language functions. Theory and Practice in Language Studies, 2(6), 1191-1198. https://doi.org/10.4304/tpls.2.6.1191-1198

Behnam, B., \& Pouriran, Y. (2009b). Classroom discourse: Analyzing teacher/learner interactions in Iranian EFL task-based classrooms. Porta Linguarum, 12, 117-132. https://doi.org/10.30827/digibug.31875

Brown, H. D. (2000). Teaching by Principles: An Interactive Approach to Language Pedagogy (p. 249): London. Longman

Christie, F. (2002). Classroom Discourse Analysis : A Functional Perspective: London. Continuum 
Dagarin, M. (2004). Classroom Interaction and Communication Strategies in Learning English as a Foreign Language. ELOPE: English Language Overseas Perspectives and Enquiries, 1(1-2), 127-139. https://doi.org/10.4312/elope.1.1-2.127-139

Ginting, S. A. (2017). The Importance of Opening Moves in Classroom Interaction. Advances in Language and Literary Studies, 8(6), 7-11. http:// ezproxy.lib.uconn.edu/login?url=https:// search.ebscohost.com/login.aspx?direct= true $\& \mathrm{db}=$ eric $\& \mathrm{AN}=\mathrm{EJ} 1165038 \&$ site $=$ ehost-live

Markee, N. (2015). The Handbook of Classroom Discourse and Interaction: Oxford. John Wiley \& Sons, Inc.

Paltridge, B., \& Phakiti, A. (2018). Research Methods in Applied Linguistics: A Practical Rescource: Sydney. Bloomsbury Academic.

Ramli, M. (2020). Classroom Discourse: Teacher Students Interaction and Gender Participation in Primary Science Education. Journal Harkat: Media Komunikasi Gender, 16 (1), 2020, 1-10, 16(1), 1-10. https://doi.org/https://doi.orh/10.15408/harkat.v16i1.14642

Rezaie, M. (2015). Reviewing Different Aspects of Classroom Discourse. International Journal of English and Education, 4(4).

Richards, J. C., \& Lockhart, C. (1994). Reflective Teaching in Second Language Classrooms. In Reflective Teaching in Second Language Classrooms. CAMBRIDGE UNIVERSITY PRESS. https://doi.org/10.1017/cbo9780511667169

Rustandi \& Mubarok. (2017). Analysis of IRF (initiantion-response-feedback) on classroon interaction. Journal of English Education, Literature and Culture, 2, 239-250.

Suherdi, D. (2010). Classroom Discourse Analysis "A Systemiotic Approach.” : Bandung UPI Press. 